\title{
Aspectos jurídicos de las Ordenanzas y Privilegios de la ciudad de Lorca (Año 1527)
}

En los albores de la reconquista de Lorca, Don Alfonso $\mathrm{X}$ el Sabio, después de otras varias prerrogativas y mercedes, le otorgó su Fuero fechado en Murcia el 20 de agosto de i27I.

Como es sabido, los Fueros suelen ser concesiones soberanas que tienden a premiar una conducta, estimular una adhesión, o ambas cosas a la vez; y de ahí que llenen de vigor y de potencia al concejo cuya existencia presupone y cuya vida jurídica regula de un modo complementario, asegurando un buen gobierno y un orden interior.

Siendo el fuero de realengo una cesión de parte de la soberanía en aquellos límites elementales y someros, suficientes para permitir a los pueblos su libre desenvolvimiento, a medida que éstos van logrando mayor importancia y su vida es más intensa y sus necesidades más complejas, aumentan las disposiciones de las cartas privilegiadas, que en los siglos XiI y xil a adoptan forma orgánica y contenido extenso, como verdaderos Códigos del derecho público y privado de la ciudad; constituyendo entre ellos tipo destacado el "Fuero de Lorca", que comprende desde la regulación del gobierno municipal hasta ordenanzas referentes a diversas materias de justicia y de orden jurídico privado.

Por esto, encaminado el Fuero a fijar y asegurar la posición política de la población, entrañando un reconocimiento de su autonomía, fué posible que al correr de los siglos formulara el Concejo de Lorca, el día 19 de marzo de 1527 , las Ordenanzas que! sancionó el emperador Don Carlos I de España y V de Alemania. 
De estas normas fundamentales de la vida local lorquina de entonces, atraen nuestra atención dos especies distintas de disposiciones que, como ahora veremos, han retonado en las regulaciones modernas de carácter nacional, como si aquéllas fueran su antecedente remoto.

No es que nosotros sostengamos un entronque directo para deducir de ello la afirmación de su linaje, sino, simplemente, hacer resaltar una similitud que tanto en lo histórico como en lo legislativo no deja de ser curiosa.

En efecto, en toda Ordenanza municipal, como prescripción de valor autonómico, existen preceptos que reflejan la situación económica, la idiosincrasia y el género de vida del pueblo que la elabora; y siendo Lorca un país agrícola, nada de particular tiene que el índice o tabla de las Ordenanzas que analizamos, contenga frecuentes referencias a los asuntos del campo y se preocupe con preferencia indudable de lo concerniente al cultivo de la tierra.

$\mathrm{Y}$ así, en la regla 79 se dice que ninguna persona que no sea vecino de esta ciudad, no sea osado de labrar en sus campos, so pena que tenga perdidos los pares y aparejos con que labrare y los barbechos, si no fuere con licencia de la ciudad; porque, de lo contrario, se sigue mucho inconveniente, y se pierden los términos y jurisdicción de la misma.

Más que una finalidad de política social, tendente a aminorar los efectos de la crisis de trabajo en los medios rurales, cual la perseguida en nuestra legislación moderna por el Decreto-ley de 28 de abril de I93I - que estableció la preferencia de los braceros de la localidad para las faenas agrícolas-, la ordenanza transcrita obedece a estímulos más poderosos de conservación de la base territorial del pueblo bajo el signo de una agricultura indígena que haga viable en todo momento la directa, fácil y total sumisión a los poderes de la ciudad, de los que se aprovechen de las tierras concejiles.

Por estos motivos, la precisión de su texto y la rigidez de la sanción penal que estatuye son mucho más vigorosas que en el decreto contemporáneo, ya que si en éste no se excluye la posibilidad de utilizar obreros forasteros cuando fueren insuficientes los locales, y se castiga la infracción de lo dispuesto con multa de 25 pesetas y 
de 50 pesetas en caso de reincidencia; en las antiguas ordenanzas lorquinas se condena a la pérdida y comiso de la yunta y la labor o sembrado a favor del concejo, salvo el caso de que éste hubiera concedido al extraño su licencia expresa para las operaciones de roturación o escalío .

El Decreto-ley de 28 de abril de I93I, fué derogado por la Ley de 28 de mayo de 1943 como restablecimiento del derecho a la libre contratación del trabajo y como solución al problema que se les planteaba a aquellos braceros avecindados en lugares de escasas perspectivas laborales. El precepto examinado de las Ordenanzas de Lorca, hace tiempo que yace en su archivo municipal como recuerdo de los afanes de antaño por la mejor organización de su vida pública, y como exponente del afecto entrañable con que aquí se cuidan las cosas del agro.

Para la mayor prosperidad del mismo y al objeto de incrementar la producción agrícola, la regla 142 ordena y manda que Cualquier persona que tuviere algún secano en los términos de esta ciudad, y no lo labrare por espacio de diez años, cualquier vecino de esta ciudad pueda entrar en dicho secano y tomarlo para sí.

Como medida de policía rural y para impedir que el desorden en las faenas agrarias lesione legítimos derechos dominicales, la ordenanza 26 dispone que ningún vecino de esta ciudad, ni forastero, ponga su mies en era ajena sin permiso de su dueño, so pena de trescientos maravedís para el juez y acusador, y de que el señor de la era pueda arrojar la tal mies fuera de ella, sin pena ninguna.

No es lo más interesante la prescripción absoluta del derecho a la tierra por el no uso durante el plazo decenal que se establece en. la primera de las ordenanzas citadas, pues en otros estatutos de igual naturaleza, como, por ejemplo, el Fuero de Arguedas y las Ordinaciones reales de la ciudad de Tarazona, por no citar otros, se contienen idénticos preceptos para regular el acotamiento de las tierras de labor a tenor del principio de la ocupación por el trabajo, que tanto importaba a la ciudad proclamar como medio para mantener en buen estado su suelo productivo y contribuir a la mayor riqueza de la población.

Tampoco es trascendental la sanción económica establecida en 
la ordenanza 26, porque en el antiguo derecho español las penas pecuniarias son abundantísimas, hasta el punto de que constituyen la base de la penalidad de la mayor parte de nuestros fueros municipales.

Lo que sí destaca es la acción directa que se reconoce en ambas disposiciones al conceder a cualquier vecino el derecho a entrar en la tierra abandonada y tomarla para sí, y al permitir al dueño de la era ocupada indebidamente, que recobre su posesión sin trámites ni consideraciones de ninguna clase.

Diríase que tales esbozos de un derecho de defensa privada son propios o exclusivos de aquellas etapas de la historia en las que el Poder público, la autoridad y las funciones estatales se hallaban todavía sin lograr su madurez, o en la imposibilidad de acudir rápidamente para restablecer un orden jurídico perturbado. $Y$ sin embargo, en la legislación actual, a pesar de que hace mucho tiempo que el Estado centralizó la coacción y la justicia, y sólo mediante él se coordinan los distintos intereses para protegerlos y limitarlos, existen muestras de auto-defensa en varias ramas del derecho, como facultad otorgada al particular agraviado para reparar, por si mismo, la lesión causada.

Dos notas típicas de autotutela, como se le ha llamado modernamente en técnica alemana, pueden verse en los artículos 592 y 6I 2 de nuestro vigente Código Civil con referencia a los casos que allí se contemplan, en los cuales se arbitra el mismo recurso expeditivo y privado que consigna la ordenanza local.

$\mathrm{Y}$ si bien estas manifestaciones de un derecho histórico, fueron abolidas cuando cesaron las circunstancias que las aconsejaron, es indudable que su principio inspirador y su propia naturaleza subsisten hoy en distintas instituciones de nuestro Código sustantivo.

Antonio Campoy, Doctor en Derecho. 